\title{
Usefulness of bladder dissection in cesarean section: a randomized controlled trial
}

\author{
Mervat A. Elsersy* \\ Department Obstetrics and Gynecology, Alexandria University, Shatby Maternity University Hospital, Egypt
}

Received: 24 September 2016

Accepted: 22 October 2016

*Correspondence:

Dr. Mervat A. Elsersy,

E-mail: msersy@hotmail.com

Copyright: $\odot$ the author(s), publisher and licensee Medip Academy. This is an open-access article distributed under the terms of the Creative Commons Attribution Non-Commercial License, which permits unrestricted non-commercial use, distribution, and reproduction in any medium, provided the original work is properly cited.

\section{ABSTRACT}

Background: There are various different methods of performing a caesarean section. With the increasing rate of repeat cesarean sections, it is necessary to recognize evidence based techniques to improve outcomes and minimize complications. Dissection of a bladder flap was an integral step in standard cesarean section. Cancelation of the bladder dissection is one the modifications that showed to be safe and cost effective. The aim of this study is to perform a randomized controlled clinical trial to evaluate the effects of cancelling the bladder dissection.

Methods: 1674 patients were enrolled in the study from May 2013 until October 2015. The patients were assigned for non-emergent cesarean section above 32 weeks. They were randomly allocated in the 2 groups.Group 1:838 patients to whom uterine incision made without incision or dissection of the bladder peritoneum. Group 2: 836 patients to whom incision and dissection of a bladder peritoneum done prior to uterine incision.

Results: Significant reduction of the total operating time, skin to delivery time, micro hematuria, dysuria, urinary retention, blood loss in group 1. The were insignificant difference between the groups as regards hospital days, febrile morbidity, wound infection rate, admission to neonatal intensive care unit and readmission rate.

Conclusions: Non dissection of the bladder peritoneum achieved short-term advantages as regards reduction of operating time, incision-delivery duration and decreased blood loss; long-term effects still to be studied.

Keywords: Bladder dissection, Blood loss, Cesarean section, Time to delivery interval

\section{INTRODUCTION}

Caesarean section is the commonest surgical procedure done on females worldwide and surgical techniques differ widely. ${ }^{1-3}$

With the rising numbers of repeat cesarean sections, it is necessary to recognize evidence based techniques to improve outcomes and decrease complications. ${ }^{2,4,5}$

The Caesarean section entails exposure of the uterus by entering the abdomen through the abdominal wall. The peritoneum covering the uterus is usually also entered. The bladder is reflected from the lower uterine segment. The uterus is then opened and the fetus and placenta are delivered. ${ }^{6}$
Dissection of the bladder flap is an essential step of the standard cesarean section. The bladder flap is performed by superficially cutting and dissecting the peritoneum to separate the bladder from the uterus. ${ }^{7}$ Before the antibiotic era, the purpose for the bladder flap was to enable the surgeon to access to the lower uterine segment without injury to the bladder. Its subsequent closure was thought to prevent transmission of intrauterine infection to the peritoneal cavity. ${ }^{8-10}$ recently recognized that closure of the bladder flap is not necessary and has been abandoned. ${ }^{7-9,11-16}$

In emergency cesarean sections, rapid delivery should be achieved; the bladder dissection is commonly cancelled. ${ }^{11,13}$ A simple method of cesarean section (Pelosi-type) including omission of the bladder dissection 
is one the modifications that showed to be safe and cost effective. $^{17}$

The goal of this study is to employ a well-designed randomized controlled clinical trial to evaluate the effects of omitting the bladder dissection at cesarean section. We hypothesize that omission of the bladder dissection in both primary and repeat cesarean sections will be associated with shorter operating time without a significant increase in intraoperative and postoperative complications.

\section{METHODS}

Type of the study was interventional.

\section{Study design}

- Allocation: Randomized

- Endpoint Classification: Safety/Efficacy Study

- Intervention Model: Parallel Assignment

- Masking: Open Label

- $\quad$ Primary Purpose: Treatment.

\section{Primary outcome measures}

Total operating time (from skin incision to closure of the skin).

\section{Secondary outcome measures}

- Skin incision to delivery time,

- Skin incision to facial closure time,

- Blood loss,

- Hematuria, dysuria, urinary retention,

- Febrile morbidity,

- Hospital days,

- Wound infection,

- Neonatal outcomes, and

- Re-admissions

Enrollment: 1674 patients, study start date: May 2013, study completion date: October 2015.

\section{Patient groups}

Group 1: No Bladder Dissection Group, Uterine incision made $1 \mathrm{~cm}$ above the vesico-uterine reflection without incision and dissection of the bladder peritoneum.

Group 2: Bladder Dissection Group, Standard cesarean section technique with incision and dissection of a bladder flap prior to uterine incision.

\section{Eligibility}

Ages eligible for study was 19 years to 46 years.

Genders eligible for study was female.

\section{Inclusion criteria}

Patients undergoing elective primary and repeat cesarean sections at or greater than 32 week's gestation.

\section{Exclusion criteria}

Non elective cesarean sections planned vertical uterine incision, previous abdominal surgeries, sedation and inability to obtain consent.

\section{RESULTS}

The demographic data of the patients in both groups were shown in Table 1; statistical analysis of these data shows no significant differences as regards the two study groups.

Table 1: Comparison between the two groups according to demographic data.

\begin{tabular}{|c|c|c|c|}
\hline & $\begin{array}{l}\text { Group I } \\
(\mathrm{n}=\mathbf{8 3 8})\end{array}$ & $\begin{array}{l}\text { Group II } \\
(\mathrm{n}=\mathbf{8 3 6})\end{array}$ & p \\
\hline \multicolumn{4}{|c|}{ Age group (years) } \\
\hline $19-<30$ & $398(47.5 \%)$ & $372(44.5 \%)$ & \multirow{3}{*}{0.437} \\
\hline $30-<40$ & $302(36 \%)$ & $313(37.4 \%)$ & \\
\hline $40-49$ & $138(16.5 \%)$ & $151(18.1 \%)$ & \\
\hline \multicolumn{4}{|c|}{ Body mass index $\left(\mathrm{kg} / \mathrm{m}^{2}\right)$} \\
\hline$<19$ & $83(9.9 \%)$ & $91(10.9 \%)$ & \multirow{4}{*}{0.319} \\
\hline $19-<22$ & $156(18.6 \%)$ & $182(21.8 \%)$ & \\
\hline $22-<25$ & $394(47 \%)$ & $373(44.6 \%)$ & \\
\hline$\geq 25$ & $205(24.5 \%)$ & $190(22.7 \%)$ & \\
\hline \multicolumn{4}{|c|}{ Gestational age at c/s (weeks) } \\
\hline $32-<36$ & $132(15.8 \%)$ & $136(16.3 \%)$ & \multirow{3}{*}{0.901} \\
\hline $36-<40$ & $409(48.8 \%)$ & $399(47.7 \%)$ & \\
\hline$\geq 40$ & $297(35.4 \%)$ & $301(36 \%)$ & \\
\hline \multicolumn{4}{|c|}{ History of chronic medical disease } \\
\hline & $167(19.9 \%)$ & $180(21.5 \%)$ & 0.433 \\
\hline \multicolumn{4}{|l|}{ Education } \\
\hline Illiterate & $163(19.5 \%)$ & $151(18.1 \%)$ & \multirow{2}{*}{0.467} \\
\hline Educated & $675(80.5 \%)$ & $685(81.9 \%)$ & \\
\hline \multicolumn{4}{|l|}{ Residency } \\
\hline Rural area & $233(27.8 \%)$ & $251(30 \%)$ & \multirow{2}{*}{0.317} \\
\hline Urban area & $605(72.2 \%)$ & $585(70 \%)$ & \\
\hline
\end{tabular}

Qualitative data were described using number and percent and was compared using Chi square test.

Data shows the total operating time in group 1 ranges from 25 to 140 minutes with median of $40 \pm 11.4$ minutes which is significantly shorter than that of group 2 .

Also the skin incision to delivery time in group 1 is $(5 \pm 1.3 \mathrm{~min}$ range $1-20 \mathrm{~min})$ which is significantly shorter than that of group 2. Analysis of data shows significantly less micro hematuria, dysuria, urine retention (16 patients $1.9 \%$ ) in group 1 when compared to group 2 . There is significant decrease in delta $\mathrm{Hb}$ level range post-operative in group $2(1.1 \pm 0.6$ range $0.6-2.1 \mathrm{gm} / \mathrm{dl})$ 
in comparison to group $1(0.6 \pm 0.4$ range $0.11-1 \mathrm{gm} / \mathrm{dl})$ which signifies that is dissection of the bladder peritoneum during cesarean section is associated with increased blood loss, Table 2.

Table 2: Comparison between the two groups according to primary and secondary outcomes.

\begin{tabular}{|lll|l|}
\hline Outcome & $\begin{array}{l}\text { Group 1 } \\
838\end{array}$ & $\begin{array}{l}\text { Group 2 } \\
836\end{array}$ & p \\
\hline $\begin{array}{l}\text { Total operating time (from skin incision to closure of the skin). Range } \\
\text { and median (minutes) }\end{array}$ & $25-140(40)$ & $45-180(45)$ & $<0.001 *$ \\
\hline Skin incision to delivery time, range and median (minutes) & $1-20(5)$ & $3-45(7)$ & $<0.001 *$ \\
\hline Skin incision to fascial closure time, range and median (minutes) & $10-55(30)$ & $30-90(45)$ & $<0.001 *$ \\
\hline Micro hematuria, dysuria, urinary retention (patients) & $16(1.9 \%)$ & $205(24.5 \%)$ & $<0.001 *$ \\
\hline Hospital days, range and median (days) & $1-2.7(2.3)$ & $2.2-3.7(2.4)$ & 0.173 \\
\hline Febrile morbidity (patients) & $73(8.7 \%)$ & $93(11.1 \%)$ & 0.099 \\
\hline Blood loss, decrease in delta Hb level, range and median (gm/dl) & $0.11-1(0.6)$ & $0.6-2.1(1.1)$ & $<0.001 *$ \\
\hline Wound infection (patients) & $102(12.2 \%)$ & $125(15 \%)$ & 0.097 \\
\hline Admission to neonatal intensive care unit (patients) & $62(7.4 \%)$ & $80(9.6 \%)$ & 0.111 \\
\hline Re-admissions & $64(7.6 \%)$ & $83(9.9 \%)$ & 0.098 \\
\hline
\end{tabular}

Abnormally Quantitative data was expressed using Median (Min - Max) and was compared using Mann Whitney test. Qualitative data were described using number and percent and was compared using Chi square test.

*: Statistically significant at $\mathrm{p} \leq 0.05$

On the other side analysis of results shows no significant difference as regards hospital days in group 1 (2.3 days range 1-2.7 days) when compared to group 2. Also there is insignificant difference in wound infection rate in group 2: (125 patients $15 \%$ ) when compared to group 1: (102 patients $12.2 \%$ ) with $\mathrm{p} 0.097$. there was insignificant difference as regards admission to neonatal intensive care unit in group 1 (62 babies $7.4 \%$ ) when compared to group 2 (80 babies $9.6 \%$ ) with p 0.111 . there was insignificant difference as regards readmission rate in both groups, Table 2.

\section{DISCUSSION}

The results of the study showed significant benefits from cancellation of bladder dissection in primary and repeat caesarean sections as regards reduction of operative time, blood loss, post-operative micro-haematuria and urine retention which matches the results of Pelosi and Ortega who introduced elimination of the bladder dissection in CS. $^{17}$

Also Chigbu et al concluded that cancellation of the bladder dissection at CS is associated with better shortand long-term outcomes. ${ }^{11}$ Because non dissection of the bladder caused less trauma and vascular injury, subsequently less additional haemostatic sutures were done. Also they stated that non dissection of the bladder prevented the incision from being made too low, which prevented dehiscence of cervix when it was fully dilated. ${ }^{18}$

Bladder injuries are rare complications of caesarean but when they happen are usually due to difficulty encountered while dissecting the bladder peritoneum, which seems similar to the results concluded in this study.

The results of this study match the results of other 2 studies where the postoperative microhematuria was fewer, which reflected a reduced manipulation and trauma of the urinary bladder. ${ }^{11,12}$ Also Hohlagschwandtner et al concluded that CS without the formation of a bladder flap provided a number of significant short-term benefits. ${ }^{12}$

Only one study evaluated omission of the bladder flap as the only modification. This single randomized trial compared omission of the bladder flap in 53 patients to the standard technique of caesarean section in 49 patients, results showed significant short term benefits of omitting the bladder flap including a less operating time, blood loss, postoperative pain and microhematuria.

Also similar results published by Malvasi et al who performed a study on 474 women, their results concluded that bladder visceral peritoneum suturing of women requiring CS for dystocia is associated to increased rate of blood collection in the vesico-uterine space, which could possibly explain the higher rate of puerperal complications in these patients. ${ }^{8}$

Similar results were suggested by Bamigboye who confirmed that suturing of bladder visceral peritoneum could lead to a pocket formation on the vesico-uterine space, with a subsequent hematoma formation, while Nagele et al reported an increased rate of febrile morbidity and cystitis when parietal peritoneum was closed, probably caused by the formation of subperitoneal pockets caused by the sutures used; these pockets could fill with blood and wound secretions from 
the uterine incision and serve as nutrient media for bacteria. $^{9,19}$

On the contrary the results of this study don't match with Faricy who stated that the purpose of the dissection of the bladder visceral peritoneum was performed so as to enable the surgeon to gain access to the lower uterine segment while minimizing injury to the bladder. Its closure was thought to avoid transmission of infection to the peritoneal cavity from intrauterine infection. ${ }^{20}$

\section{CONCLUSION}

Non dissection of the bladder flap provides short-term advantages such as reduction of operating time, incisiondelivery interval, reduced blood loss; Long-term effects remain to be evaluated.

\section{ACKNOWLEDGEMENTS}

I am so grateful to all member staff of Obstetrics and Gynaecology department In Shatby Maternity University Hospital, Faculty of Medicine, Alexandria University.

Funding: No funding sources

Conflict of interest: None declared

Ethical approval: Not required

\section{REFERENCES}

1. Dumont A, de Bernis L, Bouvier-Colle MH, Breart G. Caesarean section rate for maternal indication in sub-Saharan Africa: A systematic review. Lancet (London, England). 2001;358(9290):1328-33.

2. Dodd JM, Anderson ER, Gates S. Surgical techniques for uterine incision and uterine closure at the time of caesarean section. The Cochrane database of systematic reviews. 2008(3):Cd004732.

3. Kazmi T, Saiseema St, Khan S. Analysis of Cesarean Section Rate- According to Robson's 10-group Classification. Oman Medical Journal. Sep 2012;27(5):415-7.

4. Demers S, Roberge S, Afiuni YA, Chaillet N, Girard I, Bujold E. Survey on uterine closure and other techniques for Caesarean section among Quebec's obstetrician-gynaecologists. J Obstet Gynaecol Can. 2013;35(4):329-33.

5. Kaplanoglu M, Karateke A, Un B, Akgor U, Baloglu A. Complications and outcomes of repeat cesarean section in adolescent women. International Journal Of Clinical and Experimental Medicine. 2014;7(12):5621-8.

6. Aabakke AJ, Secher NJ, Krebs L. [Evidence-based surgical techniques for caesarean section]. Ugeskrift for laeger. 2014;176(7a):V09130535.

7. Mahajan NN. Justifying formation of bladder flap at cesarean section? Arch Gynecol Obstet. Jun 2009;279(6):853-5.
8. Malvasi A, Tinelli A, Guido M, Zizza A, Farine D, Stark M. Should the visceral peritoneum at the bladder flap closed at cesarean sections? A postpartum sonographic and clinical assessment. J Matern Fetal Neonatal Med. 2010;23(7):662-9.

9. Bamigboye AA, Hofmeyr GJ. Non-closure of peritoneal surfaces at caesarean section: A systematic review. South African Medical Journal. SuidAfrikaanse Tydskrif Vir Geneeskunde. 2005;95(2):123-6.

10. Bamigboye AA, Hofmeyr GJ. Closure versus nonclosure of the peritoneum at caesarean section. The Cochrane database of systematic reviews. 2003(4):Cd000163.

11. Chigbu CO, Ezeome IV, Iloabachie GC. Nonformation of bladder flap at cesarean section. Int $\mathbf{J}$ Gynaecol Obstet. 2006;95(3):284-5.

12. Hohlagschwandtner $M$, Ruecklinger E, Husslein $P$, Joura EA. Is the formation of a bladder flap at cesarean necessary? A randomized trial. Obstet Gynecol. 2001;98(6):1089-92.

13. Honig J. Is the formation of a bladder flap at cesarean necessary? A randomized trial. Obstet Gynecol. 2002;99(4):677-8.

14. Malvasi A, Tinelli A, Guido M, Cavallotti C, Dell'Edera D, Zizza A. Effect of avoiding bladder flap formation in caesarean section on repeat caesarean delivery. Eur J Obstet Gynecol Reprod Biol. 2011;159(2):300-4.

15. Mahajan NN, Mahajan K. Utility of the bladder flap at cesarean delivery: a randomized controlled trial. Obstet Gynecol. 2012;120(3):708-9.

16. Malvasi A, Tinelli A, Gustapane S, Mazzone E, Cavallotti C, Stark M, et al. Surgical technique to avoid bladder flap formation during cesarean section. G Chir. 2011;32(11-12):498-503.

17. Pelosi MA, Ortega I. [Cesarean section: Pelosi's simplified technique]. Rev Chil Obstet Ginecol. 1994;59(5):372-7.

18. Soper DE, Brockwell NJ, Dalton HP. The importance of wound infection in antibiotic failures in the therapy of postpartum endometritis. Surgery, gynecology and obstetrics. 1992;174(4):265-9.

19. Nagele F, Karas H, Spitzer D, Staudach A, Karasegh $\mathrm{S}$, Beck A, et al. Closure or nonclosure of the visceral peritoneum at cesarean delivery. Am J Obstet Gynecol. 1996;174(4):1366-70.

20. Faricy PO, Augspurger RR, Kaufman JM. Bladder injuries associated with cesarean section. J Urol. 1978;120(6):762-3.

Cite this article as: Elsersy MA. Usefulness of bladder dissection in cesarean section: a randomized controlled trial. Int J Reprod Contracept Obstet Gynecol 2016;5:4317-20. 